\title{
Population genetic structure of the shovel-nosed lobster Thenus unimaculatus (Decapoda, Scyllaridae) in Indian waters based on RAPD and mitochondrial gene sequences
}

\author{
N. S. Jeena • A. Gopalakrishnan · J. K. Kizhakudan • \\ E. V. Radhakrishnan • Raj Kumar • P. K. Asokan
}

Received: 13 December 2014/Revised: 19 August 2015/ Accepted: 19 August 2015

(C) Springer International Publishing Switzerland 2015

\begin{abstract}
Thenus unimaculatus is one of the most important commercially exploited lobster species in India. The declining trend in catches as well as collapse of fishery in some localities necessitated assessment of the stock structure to manage this resource sustainably. We ascertained the genetic stock structure of T. unimaculatus along the Indian coast, using molecular markers. RAPD and concatenated dataset of mitochondrial DNA genes (partial sequences of Cytochrome Oxidase I and Cytochrome $b$ ) were used to detect population differentiation. RAPD markers showed moderate genetic variability with an overall $G_{\mathrm{ST}}$ value of 0.0442 , which indicated low genetic differentiation among subpopulations. The mtDNA dataset revealed high haplotype diversity coupled with very low nucleotide diversity that suggested recent population expansion after a period of low effective population size. The median-joining haplotype network showed no geographical clustering
\end{abstract}

Handling editor: Christian Sturmbauer

N. S. Jeena $(\bowtie) \cdot$ R. Kumar

National Bureau of Fish Genetic Resources (NBFGR)

Cochin Unit, CMFRI Campus, Cochin, India

e-mail: jeenans@rediffmail.com

Present Address:

N. S. Jeena · A. Gopalakrishnan · J. K. Kizhakudan ·

E. V. Radhakrishnan · P. K. Asokan

Central Marine Fisheries Research Institute (CMFRI),

Cochin, India of haplotypes. The low levels of genetic differentiation with non-significant $P$ values $\left(F_{\mathrm{ST}}=0.0593\right)$ may be due high connectivity among shovel-nosed lobster populations and resultant panmixia. This may be due to the planktonic phyllosoma larval phase that extends for $>1$ month in wild and their transport and dispersal by monsoon currents of Northern Indian Ocean. The results of this study will aid in better management of this dwindling resource.

Keywords Thenus unimaculatus $\cdot$ RAPD $\cdot$ mtDNA · Population genetic structure

\section{Introduction}

Scyllarid lobsters contribute to about $3.69 \%$ of the world's lobster production of 279,000 tonnes (FAO, 2010). Thenus Leach, 1815 (Decapoda, Scyllaridae) is the most commercially significant of the seven scyllarid genera (Jones, 1993) with many common names such as shovel-nosed lobster, slipper lobster, flathead lobster and bay lobster. Among the multi-species lobster fishery in India, the most important ones that contributed to the fishery in 2010 were the shovelnosed lobster, Thenus unimaculatus Burton \& Davie, 2007 and the scalloped spiny lobster, Panulirus homarus (Linnaeus, 1758) (CMFRI, 2011). Earlier studies and reports of the genus Thenus in India were based on the single species-Thenus orientalis (Chacko, 1967; Deshmukh, 2001; Kizhakudan et al., 
2004a; Vijayakumaran \& Radhakrishnan, 2011). However, in view of the species revision of the genus (Burton \& Davie, 2007), the species distributed and caught widely along the coast was ascertained to be $T$. unimaculatus (Jeena et al., 2011). This bottom-dwelling species forms an important fishery along the northwest and southeast coasts (Radhakrishnan et al., 2013) and prefers sandy and muddy habitat of $10-50 \mathrm{~m}$ depth (FAO, 2010). It is one of the two scyllarid lobsters whose captive breeding and larval rearing had been successful (Kizhakudan et al., 2004a) but yet to be grown to a commercial level. $T$. unimaculatus is slow growing, less fecund (Kagwade \& Kabli, 1996) with an average of 39,300 eggs for reproductively active females (Kizhakudan, 2014) and has a planktonic larval life of 26-45 days in coastal waters over continental shelf (Kizhakudan et al., 2004a; Radhakrishnan et al., 2007). The species is fast emerging as a new candidate of aquaculture interest because of shorter larval life, hardiness and good market value (Vijayakumaran \& Radhakrishnan, 2011). Unfortunately, landings of Thenus spp. had drastically decimated over a span of a decade (1991-2001) (Kizhakudan, 2006). The collapse of the flourishing fishery of Thenus orientalis in Mumbai by 1994 is considered as a classic example of recruitment over fishing (Deshmukh, 2001).

Stock identification is mandatory for the management of commercially exploited shellfish resources to ensure their long-term sustainability. Intense fishing in certain habitats may lead to the exclusion of distinct locally adapted stocks, loss of diversity and the adaptive potential of the species. T. unimaculatus have suffered strong decline due to intensified fishing pressure even though measures like minimum legal size for export as well as participatory management approach has been implemented to regulate stock depletion (Radhakrishnan et al., 2005). This situation calls for immediate management action to save the sinking stock, which cannot be done without knowing the stock pattern or genetic structure of the species and connectivity among populations. Reliance on single genetic marker diminishes the power to detect significant spatial or temporal structure. Hence, this work examines the genetic diversity and population structure in T. unimaculatus from different landing centers along the Indian coast using Random Amplified Polymorphic DNA (RAPD) and mitochondrial DNA (partial sequences of COI and CYB genes) markers.
RAPD (Welsh \& McClelland, 1990) technique has been proved to be quick and effective for the detection of intra and interspecific genetic polymorphism in Crustacea (Baratti et al., 2003). MtDNA markers were found to be efficient to detect population structure, genetic diversity and divergence times in slipper lobsters (e.g. Rodríguez-Rey et al., 2013). Except for the major works on biology, breeding and stock assessment, the population genetic structure analysis of wild shovel-nosed lobsters has not been undertaken so far in the country. This work was a preliminary attempt for the same.

\section{Materials and methods}

\section{Sample collection and DNA extraction}

T. unimaculatus (240 nos., 60 from each centre) was collected from four locations throughout the range of species distribution along the Indian coast. Sampling was done during 2006 and 2007 from Veraval, Gujarat $\left(20^{\circ} 54^{\prime \prime} \mathrm{N} 70^{\circ} 22^{\prime \prime} \mathrm{E}\right)$ and Kollam, Kerala $\left(8^{\circ} 94^{\prime \prime} \mathrm{N}\right.$ $\left.76^{\circ} 55^{\prime \prime} \mathrm{E}\right)$ on the west coast and Chennai, Tamil Nadu $\left(13^{\circ} 06^{\prime \prime} \mathrm{N} 80^{\circ} 18^{\prime \prime} \mathrm{E}\right)$ and Visakhapatnam, Andhra Pra$\operatorname{desh}\left(17^{\circ} 14^{\prime \prime} \mathrm{N} 83^{\circ} 17^{\prime \prime} \mathrm{E}\right)$ on the east coast (Fig. 1). The species was identified following Burton \& Davie (2007) and tissue sample was taken from pleopods. Total DNA was extracted from all the collected individuals following the phenol-chloroform method (Sambrook \& Russell, 2001) with slight modification.

\section{RAPD electrophoresis and profile analysis}

Out of the one hundred decamer primers (Operon Technologies, Alameda, USA) screened, only those giving most polymorphic, reproducible and clear fingerprints were selected for population studies. RAPD profiles were generated for 240 individuals, 60 from each location, using nine random primers OPA-13, OPA-18, OPAC-05, OPAC-09, OPAC-11, OPAC-13, OPAC-17, OPAH -06 and OPAH-09. RAPD-PCR reactions were carried out in a PTC 200 gradient thermal cycler (M.J. research, Inc., Massachusetts, USA) using the above primers. The amplifications were performed in $25 \mu \mathrm{l}$ reactions containing $2.5 \mu \mathrm{l} 10 \times$ assay buffer, $7.5 \mathrm{pmol}$ of random primer, $200 \mu \mathrm{M}$ of each dNTP and $2 \mathrm{U}$ Taq DNA polymerase (Genei, India) and $25 \mathrm{ng}$ of template 
Fig. 1 Sampling sites of Thenus unimaculatus along the Indian coast

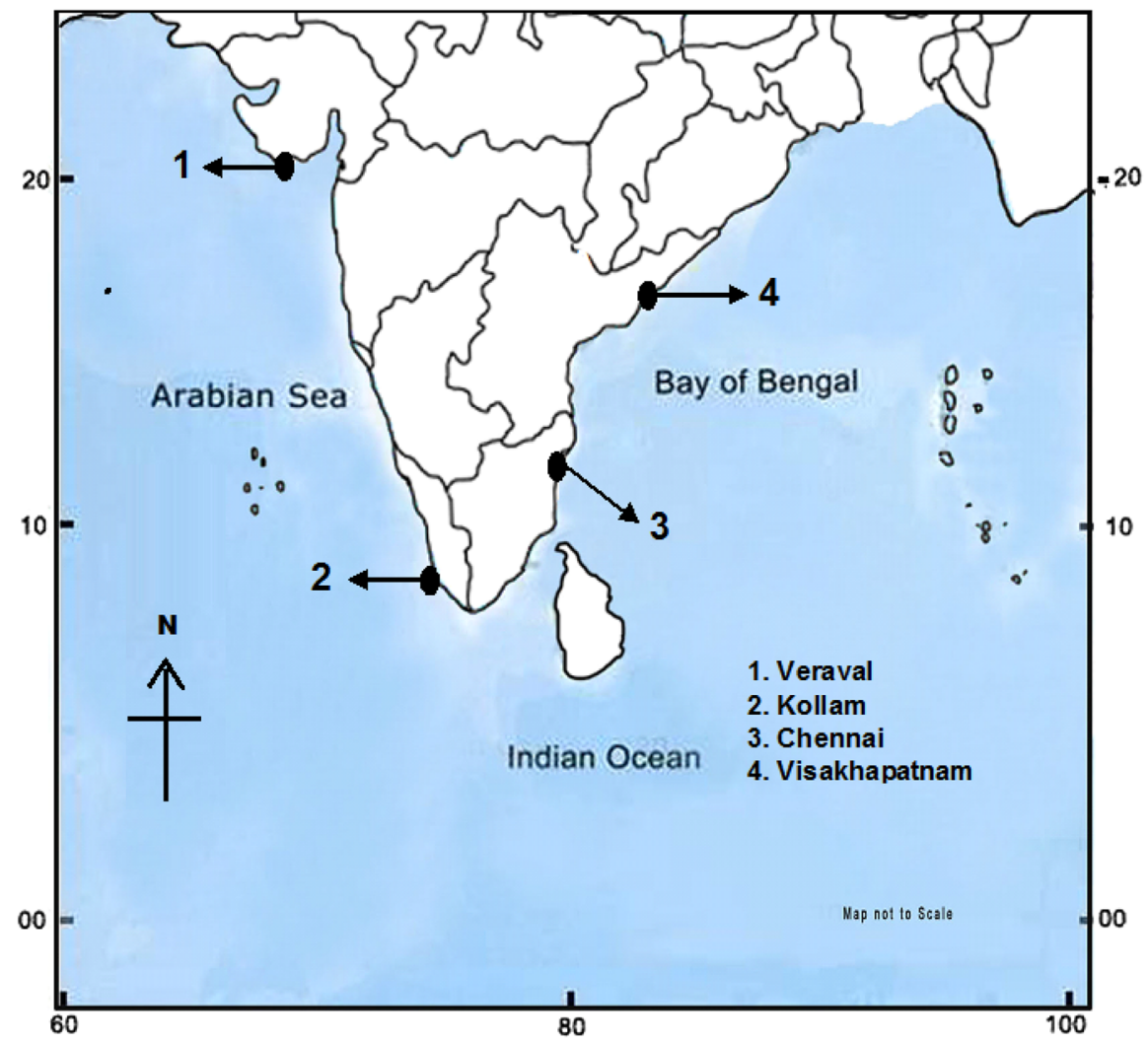

DNA. A negative control was also set up. The PCR cycling profiles were as follows: $3 \mathrm{~min}$ at $95^{\circ} \mathrm{C}$ for initial denaturation, 40 cycles of denaturation for $1 \mathrm{~min}$ at $94^{\circ} \mathrm{C}, 1 \mathrm{~min}$ annealing at $40^{\circ} \mathrm{C}, 1.30 \mathrm{~min}$ extension a $72^{\circ} \mathrm{C}$ and final extension for $10 \mathrm{~min}$ at $72^{\circ} \mathrm{C}$. PCR products were electrophoretically analysed in $1.5 \%$ agarose gel and documented using Image Master VDS (Pharmacia Biotech, USA). The sizes of DNA fragments were estimated using the software Image lab 4.0 (Image Master 1D Elite) in comparison with the molecular marker $\lambda$ DNA with Eco RI/Hind III double digest.

The presence or absence of each DNA fragment for each sample was recorded as 1 or 0 , respectively, to produce a binary matrix. Population structure analysis was carried out using the software POPGENE version 1.31 (Yeh et al., 1999). The genetic variability in four populations was assessed by the percentage of polymorphic loci $(\mathrm{P})$, gene diversity (h) and Shannon Information Index. The degree of genetic differentiation was figured by coefficient of genetic differentiation $\left(G_{\mathrm{ST}}\right)$. The genetic similarity and distances were calculated as per Nei (1978) and UPGMA-based dendrogram constructed for the species based on the above values. The bootstrap support of the dendrogram was tested using WinBoot program (Yap \& Nelson, 1996).

mtDNA sequencing and data analysis

Partial sequences of mitochondrial genes were generated using PCR employing following primer pairs: Jerry/Pat (Simon et al., 1994) for the hypervariable region of COI (800 bp) and L10061-CYB (Yamauchi et al., 2002) + H10699-CYB (Machida et al., 2002) for the CYB (650 bp). In this study, 72 sequences (18 individuals per each sampling site) were used to analyse the population structure of the species.

The amplifications were performed in $25 \mu \mathrm{l}$ reactions containing $2.5 \mu \mathrm{l} 10 \times$ assay buffer, $5 \mathrm{pmol}$ of each primer, $200 \mu \mathrm{M}$ of each dNTP and 1.5 U Taq DNA polymerase (Genei, India). The PCR cycling profiles were as follows: $5 \mathrm{~min}$ at $95^{\circ} \mathrm{C}$ for initial denaturation, 30 cycles of denaturation for $45 \mathrm{~s}$ at 
$94^{\circ} \mathrm{C}, 30 \mathrm{~s}$ annealing at $50^{\circ} \mathrm{C}$ (for CYB), $45 \mathrm{~s}$ extension at $72^{\circ} \mathrm{C}$ and final extension for $10 \mathrm{~min}$ at $72^{\circ} \mathrm{C}$. The annealing temperature had to be adjusted to $47^{\circ} \mathrm{C}$ and number of cycles increased to 40 for the COI gene amplification. PCR product along with a marker (100 bp DNA ladder) was loaded in $1.5 \%$ agarose gel, visualized and documented using Image Master VDS. The PCR product was purified using $\mathrm{GeNei}^{\mathrm{TM}}$ Quick PCR purification kit (Genei, India) followed by sequencing PCR with same primer pairs by cycle sequencing using ABI PRISM BigDye ${ }^{\circledR}$ Terminator v3.1 Cycle Sequencing Kit (Applied Biosystems).

The raw DNA sequences were edited manually and multiple alignment of sequences was performed using BioEdit sequence alignment editor version 7.0.5.2 (Hall, 1999). Haplotype number, haplotype frequency, nucleotide sequence characteristics as well as standard genetic diversity indices like gene diversity $(h)$ and nucleotide diversity $(\pi)$ within populations were analysed using the program DnaSP v 5.10.01 (Librado \& Rozas, 2009). All haplotype sequences were submitted in GenBank (Accession Numbers COI: JQ229927-JQ229938; JQ229893- JQ229900; CYB: KC951872 to KC951876). Since recombination in mtDNA is rare, a concatenated mtDNA dataset of $1281 \mathrm{bp}$ (642 bp fragment of COI and $639 \mathrm{bp}$ sequence of CYB genes) was used for population genetic structure analysis. Pairwise $F_{\mathrm{ST}}$ statistics were calculated between populations and population structure was examined through AMOVA in ARLEQUIN version 3.5 (Excoffier \& Lischer, 2010). Population demography was analysed by constructing pairwise mismatch distributions, comparing observed and expected nucleotide differences between haplotypes, under a demographic expansion model. The conformity of data to the model was validated using Tajima's ' $D$ ' (Tajima, 1989) and Fu's Fs (Fu, 1997) neutrality tests. The validity of the sudden expansion model was tested using parametric bootstrap (1000 replicates), fit to which was evaluated using the sum of square deviations ( $S S D)$ between the observed and expected mismatch as a test statistic and by Harpending's raggedness index (Hri) (Harpending, 1994) in ARLEQUIN. The genealogical relationships among haplotypes were checked through a parsimony haplotype network constructed using the software NETWORK 4.5.1.6 (Bandelt et al., 1999) and the graphical output modified manually to indicate the proportion of the particular haplotype per sampling locality.

\section{Results}

Genetic diversity, population genetic differentiation and demographic analysis

Random Amplified DNA fragments counted for 46 polymorphic bands with 27 polymorphic loci (57\%). The number of bands per primer varied from four to seven with sizes ranging from $\sim 409$ to $2200 \mathrm{bp}$. RAPD electrophoresis profiles were represented in Fig. 2, for two of the selected primers, OPAC-09 and OPAC- 17. The level of polymorphism and gene diversity were highest in samples from Kollam (30.43\% and 0.1375, respectively) while lower values were observed (15.22\% and 0.073 , respectively) for Veraval and Visakhapatnam samples. Percentage polymorphism was higher for the overall population $(58.7 \%)$ with gene diversity value of 0.1446 . Shannon's Information index ranged from 0.10 to 0.19 between groups. Genetic variability estimates in $T$. unimaculatus subpopulations using RAPD marker are given in Table 1.

Twenty different haplotypes were obtained for the concatenated mtDNA data, which contained 31 divergent nucleotide sites out of which 26 were parsimony informative. Out of these haplotypes, 15 were of low frequency and unique to a single locality. One out of the three shared haplotypes (H_3) was the most abundant in $32 \%$ of individuals from all localities. The frequency distribution of the dominant haplotypes was not significantly different among the locations. The nucleotide and haplotype diversities among four sampling sites ranged from 0.00240.0036 to $0.791-0.915$, respectively (Table 2 ). The nucleotide diversity values were high for Kollam and Chennai groups and lower for the other two, but was high (0.873) for the overall population. Nucleotide base pairs of the different haplotypes from all populations were translated into amino acid residues. Out of 247 total residues, two characters were parsimony informative.

The coefficient of genetic differentiation $\left(G_{\mathrm{ST}}\right)$ among the shovel-nosed lobster populations calculated using RAPD markers was 0.0442. Average pairwise similarity index $(S I)$ and the genetic distance based on Nei's (1978) unbiased measures between the groups of the four geographic areas were 0.928 and 0.077 , respectively (Table 3 ). The dendrogram showed low insignificant bootstrap support for the Eastern and Western groups (Fig. 3). The overall low $F_{\mathrm{ST}}(0.0593)$ 
A

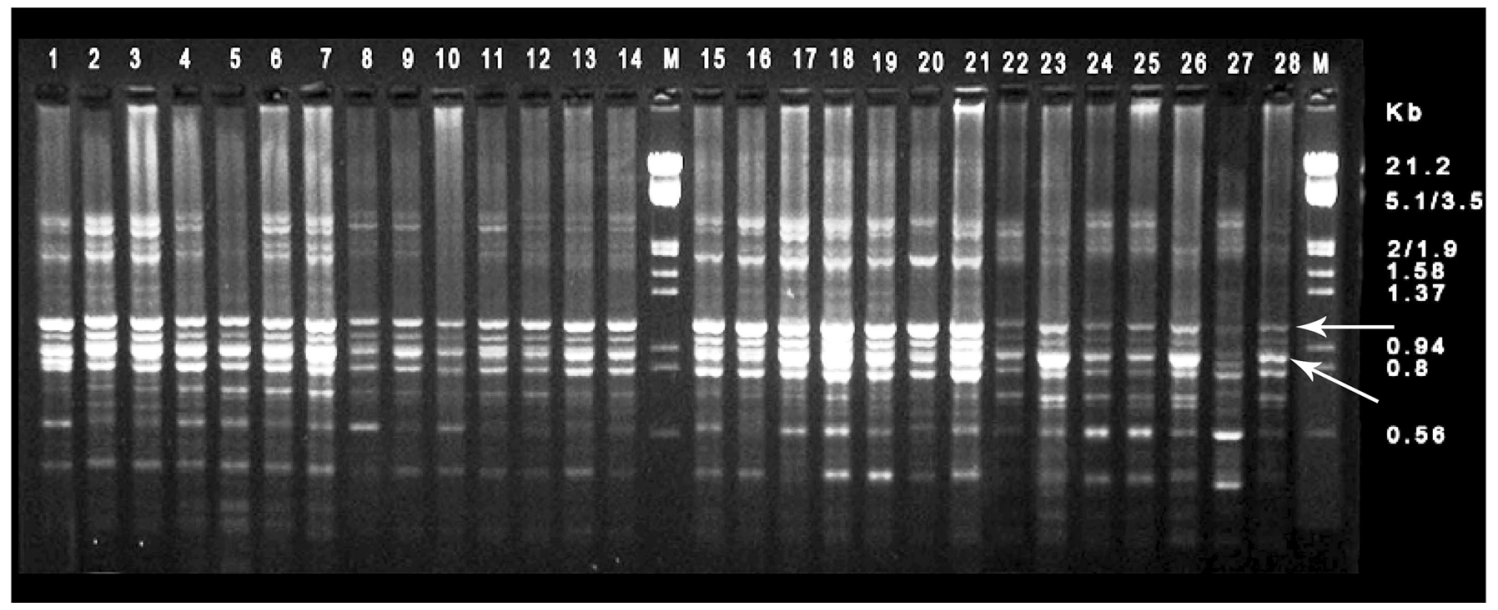

B

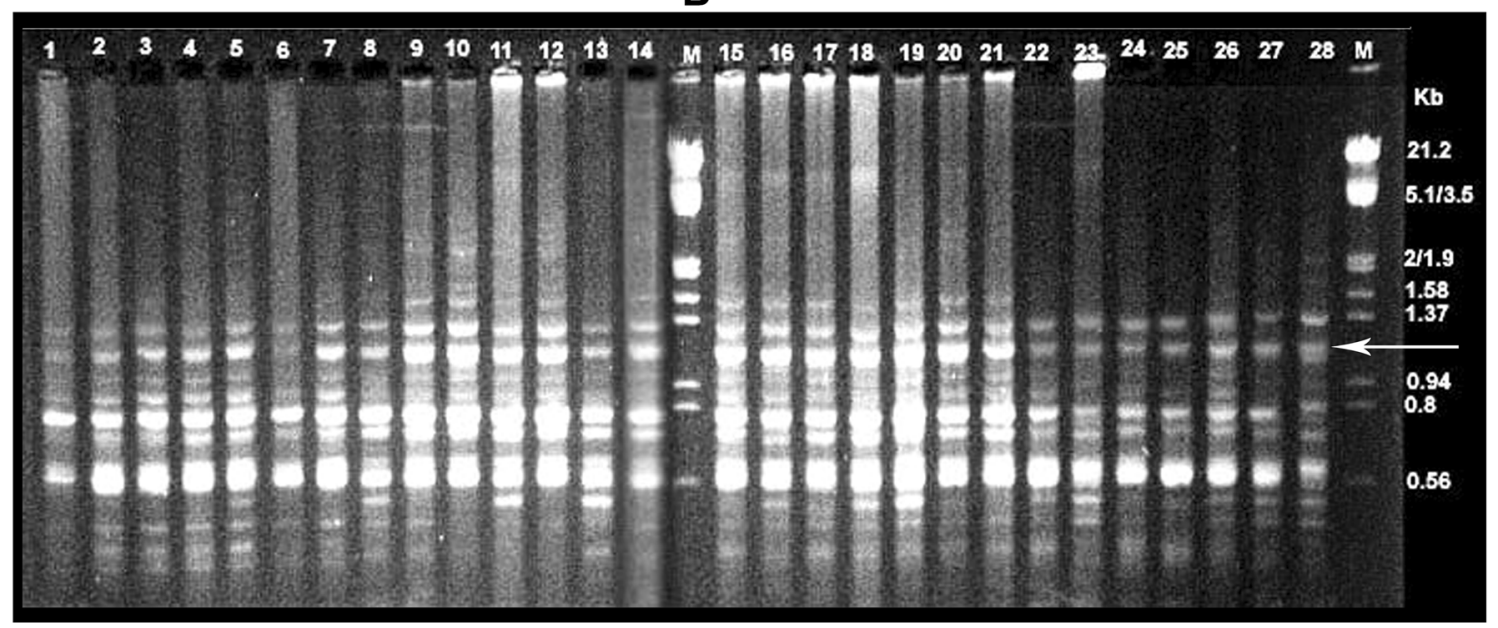

Fig. 2 RAPD patterns of T. unimaculatus generated by primers OPAC-09 (A) and OPAC-17 (B) from four sampling sites; Kollam (lanes 1-7), Veraval (lanes 8-14), Visakhapatnam (lanes 15-21) \& Chennai (lanes 22-28). M = $\lambda$ DNA with Eco $\mathrm{RI} /$ Hind III double digest. Arrowheads in right indicate specific RAPD fragments

Table 1 Genetic variability estimates for T. unimaculatus from RAPD analysis

\begin{tabular}{llllll}
\hline Parameter & Veraval & Kollam & Chennai & Visakhapatnam & Overall population \\
\hline Gene diversity $(h)$ & 0.0728 & 0.1375 & 0.1261 & 0.0718 & 0.1446 \\
Shannon information index $(I)$ & 0.1022 & 0.1957 & 0.1794 & 0.1011 & 0.2379 \\
No. of polymorphic loci & 7 & 14 & 13 & 7 & 27 \\
$\%$ polymorphism $(P)$ & 15.22 & 30.43 & 28.26 & 15.22 & 58.70 \\
\hline
\end{tabular}

and low non-significant pairwise $F_{\mathrm{ST}}$ values $(P>0.01)$ (Table 4$)$ suggested no population differentiation. AMOVA analysis showed that $94.07 \%$ of the total molecular variance was distributed within and $5.93 \%$ among localities. The parsimony median-joining network showed no geographic clustering of haplotypes. The unique and shared haplotypes were mostly related to the central haplotype (Fig. 4).

Results of Tajima's $D$ and Fu's $F s$ neutrality tests were negative and significant $(P<0.05)$ for groups from the four localities and for the overall samples. The mismatch distribution analysis spectrum was 
Table 2 Genetic diversity analysis for each and for overall population with mtDNA dataset

\begin{tabular}{llllll}
\hline & Veraval & Kollam & Chennai & Visakhapatnam & Overall \\
\hline No.of individuals analysed & 18 & 18 & 18 & 18 & 72 \\
No.of haplotypes & 5 & 9 & 9 & 5 & 20 \\
No. of polymorphic sites & 8 & 16 & 15 & 16 & 31 \\
Haplotype diversity $(h)$ & 0.797 & 0.915 & 0.843 & 0.791 & 0.873 \\
Nucleotide diversity $(\pi)$ & 0.0027 & 0.0036 & 0.0024 & 0.0034 & 0.0032 \\
\hline
\end{tabular}

Table 3 Pairwise comparison of similarity index (above diagonal) and genetic distance (below diagonal) of lobster populations calculated for RAPD primers

\begin{tabular}{lllll}
\hline & Veraval & Kollam & Chennai & Visakhapatnam \\
\hline Veraval & - & 0.9264 & 0.9228 & 0.9185 \\
Kollam & 0.0736 & - & 0.9239 & 0.9203 \\
Chennai & 0.0772 & 0.0761 & - & 0.9280 \\
Visakhapatnam & 0.0815 & 0.0797 & 0.0720 & - \\
\hline
\end{tabular}

Fig. 3 Dendrogram based on Nei's (1978) genetic distance: Method-modified UPGMA as implemented in PHYLIP v. 3.5

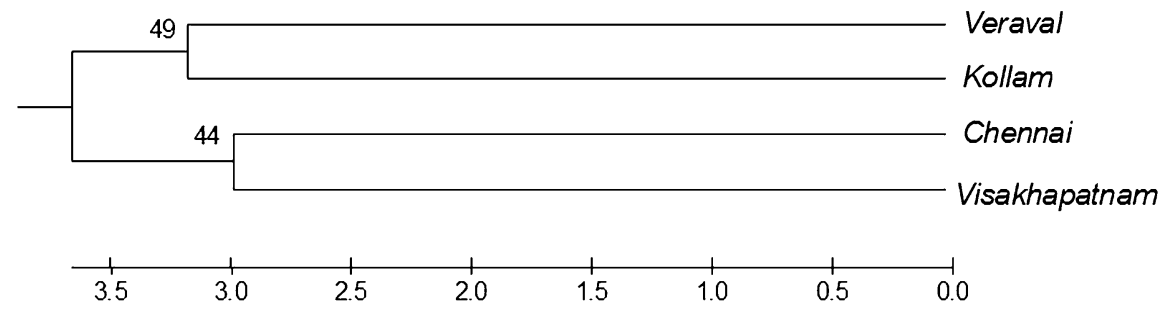

Table 4 Pairwise $F_{\mathrm{ST}}$ values (below diagonal) and their $P$ values (above diagonal) among four populations for the mtDNA dataset

\begin{tabular}{lllll}
\hline & Veraval & Kollam & Chennai & Visakhapatnam \\
\hline Veraval & - & 0.0900 & 0.02703 & 0.11712 \\
Kollam & $0.0586(-)$ & - & 0.16216 & 0.04505 \\
Chennai & $0.0765(-)$ & $0.0319(-)$ & - & 0.05405 \\
Visakhapatnam & $0.0663(-)$ & $0.0682(-)$ & $0.0622(-)$ & - \\
\hline
\end{tabular}

$(-)$ indicates not significant at $p>0.01$ after sequential Bonferroni correction

observed to be compatible with that expected under the recent expansion model (Fig. 5). The value for SSD and Hri were found to be non-significant $(P>0.05)$. The population demographic parameters are given in Table 5 .

\section{Discussion}

Genetic diversity assessment

Ensuring reproducibility of results is often cited as a major problem with the use of RAPD markers (Liu \&
Cordes, 2004). Constant experimental conditions, high-quality DNA and scoring of only bands with frequencies of at least $10 \%$ were used in this study to avoid this issue. They also suggested that six or seven primers are sufficient to assess genetic variability within and among populations of highly polymorphic species. Population structure of only a few species of lobsters had been reported (e.g. Harding et al., 1997; Ulrich et al., 2001; Park \& Yoon, 2005) utilizing eight to nine number of RAPD primers. Presuming that marine lobsters revealed high genetic polymorphism in RAPD-PCR as observed in Puerulus sewelli (Park $\&$ Yoon, 2005), the number of primers and the sample 


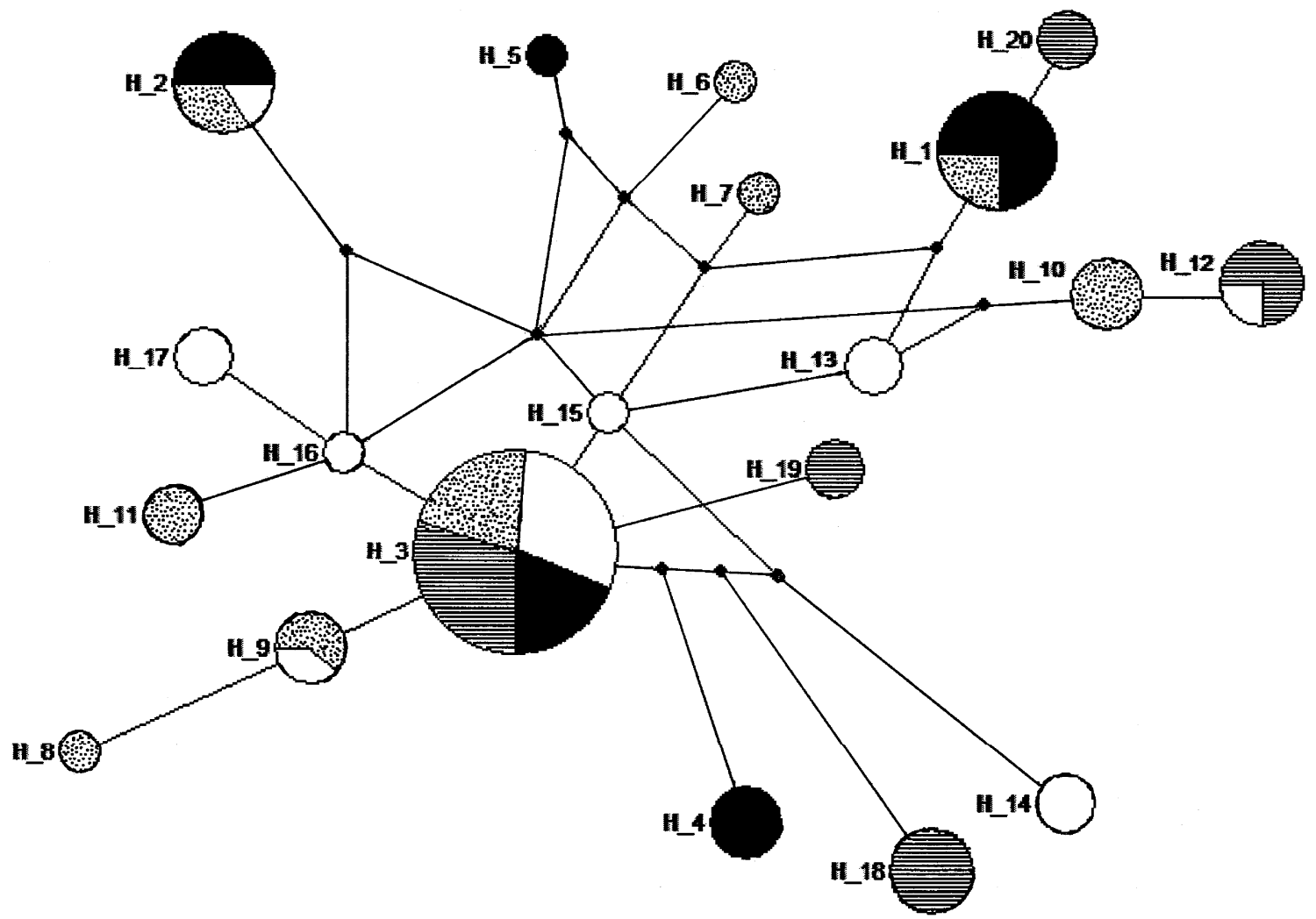

Fig. 4 Parsimony median-joining network of mtDNA dataset. Sizes of circles are proportional to the frequency of each haplotype. The black circles correspond to Veraval; dotted to Kollam; white to Chennai and striped to Visakhapatnam

Fig. 5 Mismatch distribution analysis graph for T. unimaculatus. OBS and EXP represent the observed and simulated pairwise nucleotide differences, respectively, under the population expansion model

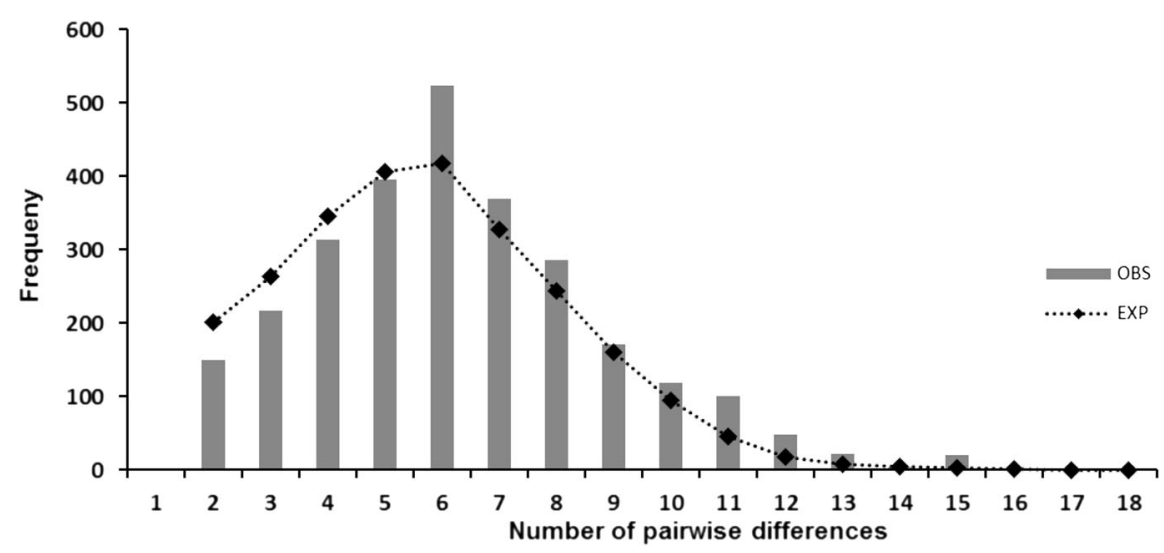

Table 5 Population demographic parameters

* Significant value at $p<0.05$

\begin{tabular}{lllll}
\hline Localities & Tajima's $D(p)$ & Fu's $F_{\mathrm{S}}(p)$ & SSD $(p)$ & Hri $(p)$ \\
\hline Veraval & $*-0.235(0.041)$ & $*-4.781(0.010)$ & $0.052(0.460)$ & $0.093(0.340)$ \\
Kollam & $*-1.333(0.034)$ & $*-7.896(0.003)$ & $0.072(0.143)$ & $0.020(0.129)$ \\
Chennai & $*-1.526(0.020)$ & $*-7.231(0.008)$ & $0.014(0.540)$ & $0.0484(0.620)$ \\
Visakhapatnam & $*-0.332(0.031)$ & $*-4.316(0.017)$ & $0.042(0.380)$ & $0.109(0.180)$ \\
Total collection & $*-1.3435(0.030)$ & $*-5.467(0.011)$ & $0.045(0.422)$ & $0.062(0.531)$ \\
\hline
\end{tabular}


size used in this study were expected to be adequate to resolve the genetic polymorphism among the shovelnosed lobsters from the four localities. Many amplified fragments using the selected RAPD primers were expressed across all groups and these specific bands can be utilized for developing SCAR (Sequence Characterised Amplified Region) markers for accurate identification of larvae and brood stock of the species. However, the species specificity of the bands has to be confirmed by using the technique in other lobster species too.

There was a high degree of uniformity among individuals in RAPD as observed in Homarus americanus (Harding et al., 1997), the variation in the band patterns being restricted to a few individuals only. The moderate level of intrapopulation polymorphism and low genetic diversity values in this nuclear marker may be due to the recent reduction in population size of $T$. unimaculatus by over-exploitation. Their restricted distribution with minimum movement from its territory (Kizhakudan et al., 2004b) may also cause a low genetic diversity.

Haplotype diversity is a measure of the uniqueness of a particular haplotype in a given population (Nei \& Tajima, 1981). The combination of high haplotype diversity and low nucleotide values indicated that $T$. unimaculatus belong to group II (high $h$ and low $\pi$ ) category of Grant \& Bowen (1998). The presence of a higher number of private haplotypes may be due to increased mutation rates, large female effective population sizes or a combination of these factors. These values indicated possibility of genetic bottleneck events, with subsequent population expansion and formation of new haplotypes in low frequencies as observed in the case of other slipper lobster species (Froufe et al., 2011; Rodríguez-Rey et al., 2013).

\section{Population structure and demographic analysis}

The overall genetic differentiation value $\left(G_{\mathrm{ST}}=0.0442\right)$ with RAPD marker indicated little genetic differentiation (Wright, 1978) in this study. Similarly low value observed with this marker in H. americanus (Harding et al., 1997) revealed the absence of genetic structure for the species. The low genetic distance and high genetic identity estimates in this case were similar to a number of observations in crustaceans (Harding et al., 1997; Aziz et al., 2010; Thangaraj et al., 2012). The
UPGMA dendrogram with low bootstrap support rejected the population grouping based on geographical proximity. The RAPD technique had revealed similar cases of low levels of gene diversity, differentiation and structuring among populations in the Brazilian silversides (Da Silva Cortinhas et al., 2010) and in parrot fishes (Geertjes et al., 2004) leading to the conclusion of homogeneous and relatively open subpopulations.

The pairwise $F_{\mathrm{ST}}$ values were low and nonsignificant between sampling locations and these local samples may be considered as a single genetic group. Negative and significant Tajima's $D$ and Fu's $F_{\mathrm{S}}$ statistical values indicated that there is departure from mutation drift equilibrium, which can be linked to an excess of unique haplotypes, and indicate selection or population expansion (Fu, 1997). The non-significant values for $S S D$ and $H r i$ suggested the goodness of fit of data expected under the model of expansion and the smoothness of unimodal expansion curve, respectively. The haplotype network with a most probable ancestral haplotype and more number of singletons again hinted that the population has recently expanded from a small number of founders following a population bottleneck (Slatkin \& Hudson, 1991). The studies within other species of lobsters in the Mozambican and South African coasts have supported the idea that species and individual populations have undergone recent population expansions (Tolley et al., 2005; Naro-Maciel et al., 2011; Rodríguez-Rey et al., 2013).

The genetic structure of marine species is determined by the complex interaction of many factors, including adult mating and pre-spawning behaviour, larval development time and behaviour, oceanography and the latter's seasonal and annual variation (Pringle $\&$ Wares, 2007), and must be empirically examined to inform management. Two possible hypotheses may be put forward to explain the connectivity among the subpopulations resulting in panmixia. (1) the pelagic larval duration of 26-45 days (2) coastal current pattern of Northern Indian Ocean associated with North East monsoon.

Pelagic larval duration is one of the fundamental components examined in the study of population connectivity (Shanks et al., 2003). In shelf areas, flow changes rapidly over short distances owing to strong interactions of frictional forces (Cowen \& Spounagle, 2009). The larvae of Thenus spp. seen over the continental shelf waters and having propagule duration 
of $>1$ month, comes under the most speculative species group proposed by Shanks (2009) in terms of dispersal distance. He predicted that passive larvae with long PDs would be dispersed offshore where they experience faster currents. Understanding the larval behaviour is the most critical aspect in determining larval connectivity (Chiswell \& Booth, 2008). Raghu Prasad (1978) observed that there was a greater concentration of larvae of both palinurids and scyllarids at 50 and $100 \mathrm{~m}$, which seemed to be closely related to the distribution of the pycnocline values. Along the west coast of India, Kathirvel (1990) observed early larval stages of lobsters far offshore and advanced stages more close to shore and correlated their abundance in night hauls to diurnal vertical movements.

The role of currents and life history of marine species have been usually considered as key elements in shaping intra-specific population structure (Muss et al., 2001). The Northern Indian Ocean comprising Bay of Bengal in the East Coast of India and Arabian Sea on the Western side is remarkable with frequent coastal currents which change direction with the seasons (Shenoi, 2010). Kathirvel \& James (1990) suggested possible emigration and immigration of larval forms through offshore or onshore currents. In India, $T$. unimaculatus breeds mainly during Nov-March along the east coast (Subrahmanian, 2004; Kizhakudan, 2006) and the peak season is during November to February along the west coast (Radhakrishnan et al., 2013). The East India Coastal Current along with Winter Monsoon Current and West India Coastal Current flows westward during Oct-Jan and there is a strong northeastward flow during March-April (Shankar et al., 1996; Shenoi, 2010). The continuously changing current pattern in the North Indian Ocean, which coincides with the peak breeding season of species, may result in the widerange dispersal of planktonic larvae of shovel-nosed lobsters along the coast, leading to genetic homogeneity. The role of currents in larval dispersal was evident in lobsters like Panulirus cygnus (Caputi et al., 1996), $P$. japonicus (Sekiguchi \& Inoue, 2010) and probably in T. indicus (Iamsuwansuk et al., 2012). However, detailed investigation is essential to prove that phyllosoma larval dispersal happens with the distribution of coastal currents along the Indian coast. It is remarkable to observe that T. unimaculatus from Phuket province on Andaman Sea in Thailand (Iamsuwansuk et al., 2012) showed $1.4 \%$ divergence in the COI region from the Indian samples, probably representing separate stocks. The reason may be the different oceanographic processes prevalent in the respective regions, which can influence larval dispersal and their settlement in preferred habitats.

The slipper lobsters tend to aggregate in the same grounds, irrespective of their developmental phase and do not undertake breeding migrations during peak spawning period (Radhakrishnan et al., 2007). Sekiguchi et al. (2007) proposed that the phyllosoma of Thenus species might not be widely dispersed though they have the potential and opined that the evolution of short larval durations in many scyllarid species may be to facilitate their recruitment to benthic inshore populations. Raghu Prasad et al. (1975) could observe greater concentration of phyllosoma larvae in $50 \mathrm{~m}$ depth near landmasses. Unlike palinurids, the phyllosomas and nisto of Thenus species are weak swimmers (Barnett et al., 1984) with a larval morphology that limit their vertical migrations. There are variations in spawning season of $T$. unimaculatus along the west and east coast (Radhakrishnan et al., 2013). All these factors together suggest that a population structuring may be possible in the case of T. unimaculatus. Lack of stock differentiation may also be due to inadequacy in sampling scheme or markers utilized (Nielsen \& Kenchington, 2001). However, both the markers used in this study seemed to support the null hypothesis. The tagging experiments conducted in Thenus spp. indicated that it could be very mobile, but not likely to be migratory (Courtney et al., 2001). Such experiments are yet to be carried out for the species along Indian coast. Although unlikely, rare individuals that disperse long distances can also smoothen genetic differences between populations (Shanks, 2009). Another reason as suggested by Chapman et al. (1999) is that similar marine environments, even geographically distant, may show homogeneous populations. This may be applicable to Thenus spp. as inferred from its habitat preference and resultant patchiness in distribution along the coast. Similar findings of genetically unstructured populations with molecular markers were reported in scyllarid lobsters (e.g. Froufe et al., 2011; Rodríguez-Rey et al., 2013) including T. unimaculatus (Wongruenpibool \& Denduangboripant, 2013). In contrast to this, the presence of substantial genetic differentiation is also not unusual in lobsters (e.g. Chow et al., 2011; Iamsuwansuk et al., 2012) suggesting that larval dispersal may not be materialized. 
The RAPD marker exposed moderate genetic diversity and high genetic identity among subpopulations. Analysis of mtDNA sequence data results revealed non-significant fixation indices with the AMOVA displaying high values for variation within population. Both the markers gave indication of panmixia. High haplotype diversity coupled with low nucleotide diversity, significant negative values of neutrality tests and the mismatch distribution analysis indicated a recent expansion in population possibly following a genetic bottleneck. Despite the relatively long distance that separates the sampling sites of shovel-nosed lobsters, the teleplanic larvae, pelagic larval duration and monsoon currents that can influence the dispersal of early stage phyllosoma may be the major factors that facilitate a high connectivity between populations.

The current results will be useful for better management of shovel-nosed lobster stocks. The catch of the brooders should be discouraged and the adults must be allowed to breed at least once in their lifetime based on their length at first maturity to ensure recruitment to population. Commercialization of the already developed hatchery technology as well as restocking in areas of decline in fishery of the species can be other strategies to replenish the stock. All management and conservation efforts must be coordinated at the national level for the panmictic stock. This was the initial study on the population genetics of lobsters from Indian waters. In the case of $T$. unimaculatus, further detailed examination of the population structure needs to be carried out using high sensitivity genetic markers like the mtDNA D-loop region or nuclear microsatellite markers for accurate investigation and confirmation of the findings.

Acknowledgments The authors are indebted to Indian Council of Agricultural Research (ICAR) and the directors of National Bureau of Fish Genetic Resources (NBFGR) and Central Marine Fisheries Research Institute (CMFRI) for providing all necessary help and support for this work. The present study was a part of $\mathrm{Ph}$. D work submitted to Cochin University of Science and Technology. The first author acknowledges Council of Scientific and Industrial Research (CSIR), India for the fellowship received to carry out this research.

\section{References}

Aziz, D., S. S. Siraj, A. Arshad, S. M. Nurul Amin \& S. A. Harmin, 2010. Population characterization of planktonic shrimp, Acetes japonicus (Decapoda: Sergestidae) using RAPD technique. Journal of Biological Sciences 10: 355-361.

Bandelt, H. J., P. Forster \& A. Röhl, 1999. Median-joining networks for inferring intraspecific phylogenies. Molecular Biology and Evolution 16: 37-48.

Baratti, M., R. Argano, A. Burchi \& G. Messana, 2003. Analysis of genetic variability of stygobitic isopod populations (Stenasellus racovitzai, Isopoda) with RAPD markers and comparison to allozyme data. Crustaceana 76: 39-47.

Barnett, B. M., R. F. Hartwick \& N. E. Milward, 1984. Phyllosoma and nisto stage of the Moreton Bay bug, Thenus orientalis (Lund) (Crustacea: Decapoda: Scyllaridae), from shelf waters of the Great Barrier Reef. Australian Journal of Marine and Freshwater Research 35: 143-152.

Burton, T. E. \& P. J. F. Davie, 2007. A revision of the shovelnosed lobsters of the genus Thenus (Crustacea: Decapoda: Scyllaridae), with descriptions of three new species. Zootaxa 1429: 1-38.

Caputi, N., W. J. Fletcher, A. Pearce \& C. F. Chubb, 1996. Effect of the Leeuwin current on the recruitment of fish and invertebrates along the Western Australian coast. Marine and Freshwater Research 47: 147-155.

Chacko, S., 1967. The central nervous system of Thenus orientalis (Leach). Marine Biology 1: 113-117.

Chapman, L. J., C. A. Chapman, D. A. Brazeau, B. McLaughlin \& M. Jordan, 1999. Papyrus swamps, hypoxia, and faunal diversification: variation among populations of Barbus neumayeri. Journal of Fish Biology 54: 310-327.

Chiswell, S. M. \& J. D. Booth, 2008. Sources and sinks of larval settlement in Jasus edwardsii around New Zealand: where do larvae come from and where do they go? Marine Ecology Progress Series 354: 201.

Chow, S., A. Jeffs, Y. Miyake, K. Konishi, M. Okazaki, N. Suzuki \& M. Sakai, 2011. Genetic isolation between the Western and Eastern Pacific populations of pronghorn spiny lobster Panulirus penicillatus. PLoS One 6: e29280.

CMFRI., 2011. Annual Report 2010-11. Central Marine Fisheries Research Institute, Cochin, India: 163.

Courtney, A. J., M. G. Cosgrove \& D. J. Die, 2001. Population dynamics of Scyllarid lobsters of the genus Thenus spp. on the Queensland (Australia) east coast: I. Assessing the effects of tagging. Fisheries Research 53: 251-261.

Cowen, R. K. \& S. Sponaugle, 2009. Larval dispersal and marine population connectivity. Annual Review of Marine Science 1: 443-466.

Da Silva Cortinhas, M. C., C. Glienke, A. J. Prioli, R. B. Noleto, D. A. Matoso \& M. M. Cestari, 2010. A prime inference on genetic diversity (RAPDs) in the marine fish Atherinella brasiliensis (Teleostei, Atherinopsidae) from Southern Brazil. Acta Zoologica 91: 242-248.

Deshmukh, V. D., 2001. Collapse of sand lobster fishery in Bombay waters. Indian Journal of Fisheries 48: 71-76.

Excoffier, L. \& H. E. Lischer, 2010. Arlequin suite ver 3.5: a new series of programs to perform population genetics analyses under Linux and Windows. Molecular Ecology Resources 10: 564-567.

FAO., 2010. Fishery statistical collections: global production. Food and Agriculture Organization (FAO) of the UN.

Froufe, E., P. Cabezas, P. Alexandrino \& M. Pérez-Losada, 2011. Comparative phylogeography of three achelata 
lobster species from Macaronesia (North East Atlantic). In Held, C., S. Koenemann \& C. D. Schubart (eds), Phylogeography and Population Genetics in Crustacea. CRC Press, USA: 157-173.

Fu, Y. X., 1997. Statistical tests of neutrality of mutations against population growth, hitchhiking and background selection. Genetics 147: 915-925.

Geertjes, G. J., J. Postema, A. Kamping, W. van Delden, J. J. Videler \& L. van de Zande, 2004. Allozymes and RAPDs detect little genetic population substructuring in the Caribbean stoplight parrotfish Sparisoma viride. Marine Ecology Progress Series 279: 225-235.

Grant, W. A. S. \& B. W. Bowen, 1998. Shallow population histories in deep evolutionary lineages of marine fishes: insights from sardines and anchovies and lessons for conservation. Journal of Heredity 89: 415-426.

Hall, T. A., 1999. BioEdit: a user-friendly biological sequence alignment editor and analysis program for Windows 95/98/ NT. Nucleic Acids Symposium Series 41: 95-98.

Harding, G. C., E. L. Kenchington, C. J. Bird, D. S. Pezzack \& D. C. Landry, 1997. Genetic relationships among subpopulations of the American lobster (Homarus americanus) as revealed by random amplified polymorphic DNA. Canadian Journal of Fisheries and Aquatic Sciences 54: $1762-1771$.

Harpending, H. C., 1994. Signature of ancient population growth in a low-resolution mitochondrial DNA mismatch distribution. Human Biology: 591-600.

Iamsuwansuk, A., J. Denduangboripant \& P. J. F. Davie, 2012. Molecular and morphological investigations of shovelnosed lobsters Thenus spp. (Crustacea: Decapoda: Scyllaridae) in Thailand. Zoological Studies 51: 108-117.

Jeena, N. S., A. Gopalakrishnan, E. V. Radhakrishnan, J. Lijo, K. K. Joe, V. S. Basheer, J. K. Shoba, P. K. Asokan \& J. K. Jena, 2011. Molecular phylogeny of commercially important lobster species from Indian waters deduced from mitochondrial and nuclear DNA sequences. Book of Abstracts, 9th Indian Fisheries Forum, December 19-23, Chennai, India.

Jones, C. M., 1993. Population structure of Thenus orientalis and T. indicus (Decapoda: Scyllaridae) in northeastern Australia. Marine Ecology Progress Series 97: 143-155.

Kagwade, P. V. \& L. M. Kabli, 1996. Reproductive biology of the sand lobster Thenus orientalis (Lund) from Bombay waters. Indian Journal of Fisheries 43: 13-25.

Kathirvel, M., 1990. On the collections of phyllosomal larvae by Isaacs Kidd Midwater trawl from the west coast of India. In Mathew, K.J. (ed.), Proceedings of the First Workshop on Scientific Results of FORV Sagar Sampada, CMFRI: 141-146.

Kathirvel, M. \& D. B. James, 1990. The phyllosoma larvae from Andaman and Nicobar waters. In Mathew, K.J. (ed.), Proceedings of the First Workshop on Scientific Results of FORV Sagar Sampada: 147-150.

Kizhakudan, J. K., 2006. Seed Production of the Sand lobster Thenus orientalis (Lund)- CMFRI Summer School on Recent Advances in Seed Production and Growout Techniques for Marine Finfish and Shellfish (7-27 August, 2006. CMFRI, Mandapam: 217-229.

Kizhakudan, J. K., 2014. Reproductive biology of the female shovel-nosed lobster Thenus unimaculatus (Burton and
Davie, 2007) from north-west coast of India. Indian Journal of Geo-Marine Sciences 43: 927-935.

Kizhakudan, J. K., E. V. Radhakrishnan, R. M. George, P. Thirumilu, S. Rajapackiam, C. Manibal \& J. Xavier, 2004a. Phyllosoma larvae of Thenus orientalis and Scyllarus rugosus reared to settlement. The Lobster Newsletter 17.

Kizhakudan, J. K., P. Thirumilu, S. Rajapackiam \& C. Manibal, 2004b. Captive breeding and seed production of scyllarid lobsters - opening new vistas in crustacean aquaculture. Marine Fisheries Information Service, Technical and Extension Series, CMFRI 181: 1-4.

Librado, P. \& J. Rozas, 2009. DnaSP v5: a software for comprehensive analysis of DNA polymorphism data. Bioinformatics 25: 1451-1452.

Liu, Z. J. \& J. F. Cordes, 2004. DNA marker technologies and their applications in aquaculture genetics. Aquaculture 238: 1-37.

Machida, R. J., M. U. Miya, M. Nishida \& S. Nishida, 2002. Complete mitochondrial DNA sequence of Tigriopus japonicus (Crustacea: Copepoda). Marine Biotechnology 4: 406-417.

Muss, A., D. R. Robertson, C. A. Stepien, P. Wirtz \& B. W. Bowen, 2001. Phylogeography of Ophioblennius: the role of ocean currents and geography in reef fish evolution. Evolution 55: 561-572.

Naro-Maciel, E., B. Reid, K. E. Holmes, D. R. Brumbaugh, M. Martin \& R. DeSalle, 2011. Mitochondrial DNA sequence variation in spiny lobsters: population expansion, panmixia, and divergence. Marine Biology 158: 2027-2041.

Nei, M., 1978. Estimation of average heterozygosity and genetic distance from a small number of individuals. Genetics 89: 583-590.

Nei, M. \& F. Tajima, 1981. DNA polymorphism detectable by restriction endonucleases. Genetics 97: 145-163.

Nielsen, E. E. \& E. Kenchington, 2001. Prioritising marine fish and shellfish populations for conservation: a useful concept. Fish and Fisheries 2: 328-343.

Park, S. Y. \& J. M. Yoon, 2005. Genetic differences and variations in slipper lobster (Ibacus ciliatus) and deep sea lobster (Puerulus sewelli) determined by RAPD analysis. Gene and Genomics 27: 307-317.

Pringle, J. M. \& J. P. Wares, 2007. Going against the flow: maintenance of alongshore variation in allele frequency in a coastal ocean. Marine Ecology Progress Series 335: 69-84.

Radhakrishnan, E. V., V. D. Deshmukh, M. K. Manisseri, M. Rajamani, J. K. Kizhakudan \& R. Thangaraja, 2005. Status of the major lobster fisheries in India. New Zealand Journal of Marine and Freshwater Research 39: 723-732.

Radhakrishnan, E. V., M. K. Manisseri \& V. D. Deshmukh, 2007. Biology and Fishery of the Slipper Lobster, Thenus orientalis, in India. In Lavalli, K. L. \& E. Spanier (eds), The biology and Fisheries of the Slipper Lobster. CRC Press, USA: 309-324.

Radhakrishnan, E. V., R. D. Chakraborty, P. K. Baby \& M. Radhakrishnan, 2013. Fishery and population dynamics of the sand lobster Thenus unimaculatus (Burton \& Davie, 2007) landed by trawlers at Sakthikulangara Fishing Harbour in the south-west coast of India. Indian Journal of Fisheries 60: 7-12. 
Raghu Prasad, R., 1978. Studies on the Phyllosoma larvae from the Indian Ocean: I-distribution and growth. Journal of the Marine Biological Association of India 20: 143-156.

Raghu Prasad, R., P. R. S. Tampi \& M. J. George, 1975. Phyllosoma larvae from the Indian Ocean collected by the Dana Expedition 1928-1930. Journal of the Marine Biological Association of India 17: 56-107.

Rodríguez-Rey, G. T., A. M. Solé-Cava \& C. Lazoski, 2013. Genetic homogeneity and historical expansions of the slipper lobster, Scyllarides brasiliensis, in the south-west Atlantic. Marine and Freshwater Research 65: 59-69.

Sambrook, J. \& D. W. Russell, 2001. Molecular Cloning: A Laboratory Manual, 3rd ed. Cold Spring Harbor Laboratory Press, NY.

Sekiguchi, H. \& N. Inoue, 2010. Larval recruitment and fisheries of the spiny lobster Panulirus japonicus coupling with the Kuroshio subgyre circulation in the western North Pacific: a review. Journal of Marine Biological Association of India 52: 195-207.

Sekiguchi, H., J. D. Booth \& W. R. Webber, 2007. Early life histories of slipper lobsters. In Lavalli, K. L. \& E. Spanier (eds), The Biology and Fisheries of the Slipper Lobster. CRC Press, USA: 69-90.

Shankar, D., J. P. Mc Creary, W. Han \& S. R. Shetye, 1996. Dynamics of the East India Coastal Current 1. Analytic solutions forced by interior Ekman pumping and local alongshore winds. Journal of Geophysical Research 101: 13975-13991.

Shanks, A. L., 2009. Pelagic larval duration and dispersal distance revisited. The Biological Bulletin 216: 373-385.

Shanks, A. L., B. A. Grantham \& M. H. Carr, 2003. Propagule dispersal distance and the size and spacing of marine reserves. Ecological Applications 13: 159-169.

Shenoi, S. S. C., 2010. Intra-seasonal variability of the coastal currents around India: a review of the evidences from new observations. Indian journal of Geo-Marine Sciences 39: 489-496.

Simon, C., F. Frati, A. Beckenbach, B. Crespi, H. Liu \& P. Floors, 1994. Evolution, weighting, and phylogenetic utility of mitochondrial gene sequences and a compilation of conserved polymerase chain reaction primers. Annals of the entomological Society of America 87: 651-701.

Slatkin, M. \& R. R. Hudson, 1991. Pairwise comparisons of mitochondrial DNA sequences in stable and exponentially growing populations. Genetics 129: 555-562.
Subrahmanian, V. T., 2004. Fishery of sand lobster Thenus orientalis (Lund) along Chennai coast. Indian Journal of Fisheries 51: 111-115.

Tajima, F., 1989. Statistical method for testing the neutral mutation hypothesis by DNA polymorphism. Genetics 123: 585-595.

Thangaraj, M., R. Thirumaraiselvi \& J. Subburaj, 2012. Genetic variation and diversity of two brachyuran crab species (Sesarma brockii and Grapsus strigosus) in an artificially developed mangrove ecosystem. Indian Journal of Biotechnology 11: 111-113.

Tolley, K. A., J. C. Groeneveld, K. Gopal \& C. A. Matthee, 2005. Mitochondrial DNA panmixia in spiny lobster Palinurus gilchristi suggests a population expansion. Marine Ecology Progress Series 297: 225-231.

Ulrich, I., J. Muller, C. Schutt \& F. Buchholz, 2001. A study of population genetics in the European lobster, Homarus gammarus (Decapoda, Nephropidae). Crustaceana 74: 825-837.

Vijayakumaran, M. \& E. V. Radhakrishnan, 2011. Slipper Lobsters. In Fotedar, R. \& B. Phillips (eds), Recent advances and new species in aquaculture. Wiley, New York: 85-114.

Welsh, J. \& M. McClelland, 1990. Fingerprinting genomes using PCR with arbitrary primers. Nucleic Acids Research 18: 7213-7218.

Wongruenpibool, S. \& J. Denduangboripant, 2013. Genetic diversity of purple-legged shovel-nosed lobster Thenus unimaculatus in Thailand. Thai Journal of Genetics 6: 64-71.

Wright, S., 1978. Evolution and the Genetics of Populations. Variability within and among Natural Populations, Vol. 4. University of Chicago Press, Chicago.

Yamauchi, M. M., M. U. Miya \& M. Nishida, 2002. Complete mitochondrial DNA sequence of the Japanese spiny lobster, Panulirus japonicus (Crustacea: Decapoda). Gene 295: 89-96.

Yap, V. I. \& R. J. Nelson, 1996. WINBOOT: A program for performing bootstrap analysis of binary data to determine the confidence limits of UPGMA-Based dendrograms. IRRI Discussion paper series No. 14, Manila, Philippines.

Yeh, F. C., R. C. Yang, T. B. J. Boyle, Z. H. Ye \& J. X. Mao, 1999. POPGENE, the User-Friendly Shareware for Population Genetic Analysis. Molecular Biology and Biotechnology Centre, University of Alberta, Edmonton, Alta. 